\section{Studies on Foliicolous Fungi - XXVI - a new species and three new records}

\section{V.B. Hosagoudar}

Microbiology Division, Tropical Botanic Garden and Research Institute, Palode, Thiruvananthapuram, Kerala 695562, India Email: vbhosagoudar@rediffmail.com

\section{Balladyna indica sp. nov.} (Image 1)

Coloniae hypophyllae, tenues vel subdensae, patentiae, ad $10 \mathrm{~mm}$ diam., confluentes. Hyphae rectae vel subrectae, alternatim vel irregulariter acuteque vel laxe ramosae, laxe vel arte reticulatae, cellulae 19-36 x 6-8 $\mu \mathrm{m}$. Appressoria dispersa, alternata vel unilateralis, concoloura, ovata, oblonga, cylindracea, integra, recta, curvula vel uncinata, 11-20 × 6-8 $\mu \mathrm{m}$. Setae myceliales nigrae, simplices, rectae, ad apicem acutae vel obtusae, ad $144 \mu \mathrm{m}$ longae. Perithecia dispersa, globosa, ad initio stipitatis, sessilis ad maturitata, ad $100 \mu \mathrm{m}$ diam. Asci non visa. Ascosporae oblongae, conglobatae, nigrae vel brunneae, uniseptatae, fortiter constrictae ad septatae, 30-32 x 15-17 $\mu \mathrm{m}$, parietus glabrus

Colonies hypophyllous, thin to subdense, spreading, up to $10 \mathrm{~mm}$ in diam., confluent. Hyphae straight to substraight, branching alternate to irregular at acute to wide angles, loosely to closely reticulate, cells 19-36 x 6-8 $\mu \mathrm{m}$. Appressoria scattered, alternate to unilateral, concolourous, ovate, oblong, cylindrical, entire, straight, curved to uncinate, 11-20 x 6-8 $\mathrm{m}$. Mycelial setae dark, simple, straight, acute to obtuse at the tip, up to 144 $\mu \mathrm{m}$ long. Perithecia scattered, globose, initially stipitate, later sessile, up to $100 \mu \mathrm{m}$ in diameter. Asci not seen. Ascospores oblong, conglobate, dark brown, uniseptate, strongly constricted at the septum, 30-32 x 15-17 $\mathrm{m}$, wall smooth.

Etymology: Named after the country, India

\section{Material examined}

Type: 13.xii.2003, On leaves of Rubiaceae member, Sairandhri, Silent Valley, Palghat, Kerala, India, coll. V.B. Hosagoudar et al. HCIO 46695 (type), TBGT 2036 (isotype)

Date of online publication 26 July 2009

ISSN 0974-7907 (online) | 0974-7893 (print)

Editor: R.K. Verma

Manuscript details:

Ms \# 02060

Received 13 September 2008

Finally accepted 19 June 2009

Citation: Hosagoudar, V.B. (2009). Studies on Foliicolous Fungi - XXVI - a new species and three new records. Journal of Threatened Taxa 1(7): 375-377.

Copyright: (C) V.B. Hosagoudar 2009. Creative Commons Attribution 3.0 Unported License. JoTT allows unrestricted use of this article in any medium for nonprofit purposes, reproduction and distribution by providing adequate credit to the authors and the source of publication.

Acknowledgement: The author thanks the Director, TBGRI, Palode for facilities.

OPEN AGGESS | FREE DOWNLOAD

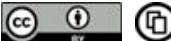

(MycoBank \# MB 513421 )

This species is close to Balladyna deightonii Hansf. (Hosagoudar 2004) in having more than $100 \mu \mathrm{m}$ long mycelial setae and $25 \mu \mathrm{m}$ long ascospores. However, Balladyna indica differs from it in having entire appressoria (Hosagoudar 2004). It also differs from B. rubiacearum Hosag. in having oblong and entire appressoria (Hosagoudar 2002).

\section{Eupelte amicta Syd., Ann. Mycol. 22:426, 1924. (Image 2)}

Colonies epiphyllous, dense, crustose, smooth, up to $10 \mathrm{~mm}$ in diameter, often cause yellow haloes around the colonies and also yellowing on the corresponding lower surface of the leaves. Hyphae partly superficial and partly immersed, superficial hyphae brown, septate, flexuous, irregularly branched at acute to wide angles, cells 12-35 x 3-4 $\mu$ m. External mycelium enters the host through stomata extended up to palisade tissues. Conidiophores arise from the external mycelium, mostly deep brown to rarely dark, 0-1-septate, erect, often curved, simple,

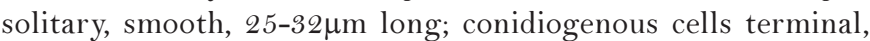
integrated, monoblastic, determinate; conidia brown, 0-3septate, not constricted, straight to curved, cylindrical, obclavate, broadly rounded at the apex, truncate at the base,

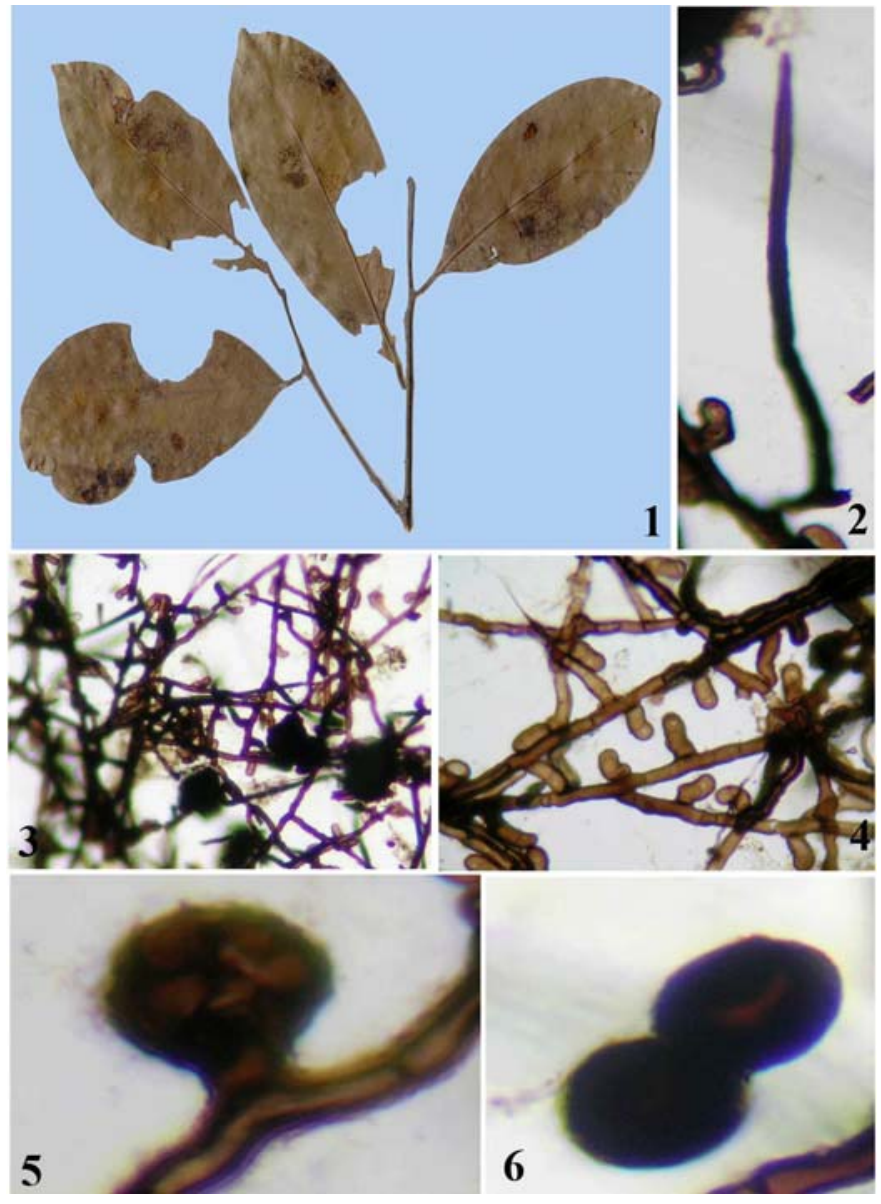

Image 1. Balladyna indica sp. nov. on Rubiaceae member 1 - Infected leaves; 2 - Mycelial seta; 3 - Mycelial colony with black perithecia; 4 - Appressoria with hyaline spots; 5 - Developing stipitate perithecium; 6 - Ascospore 


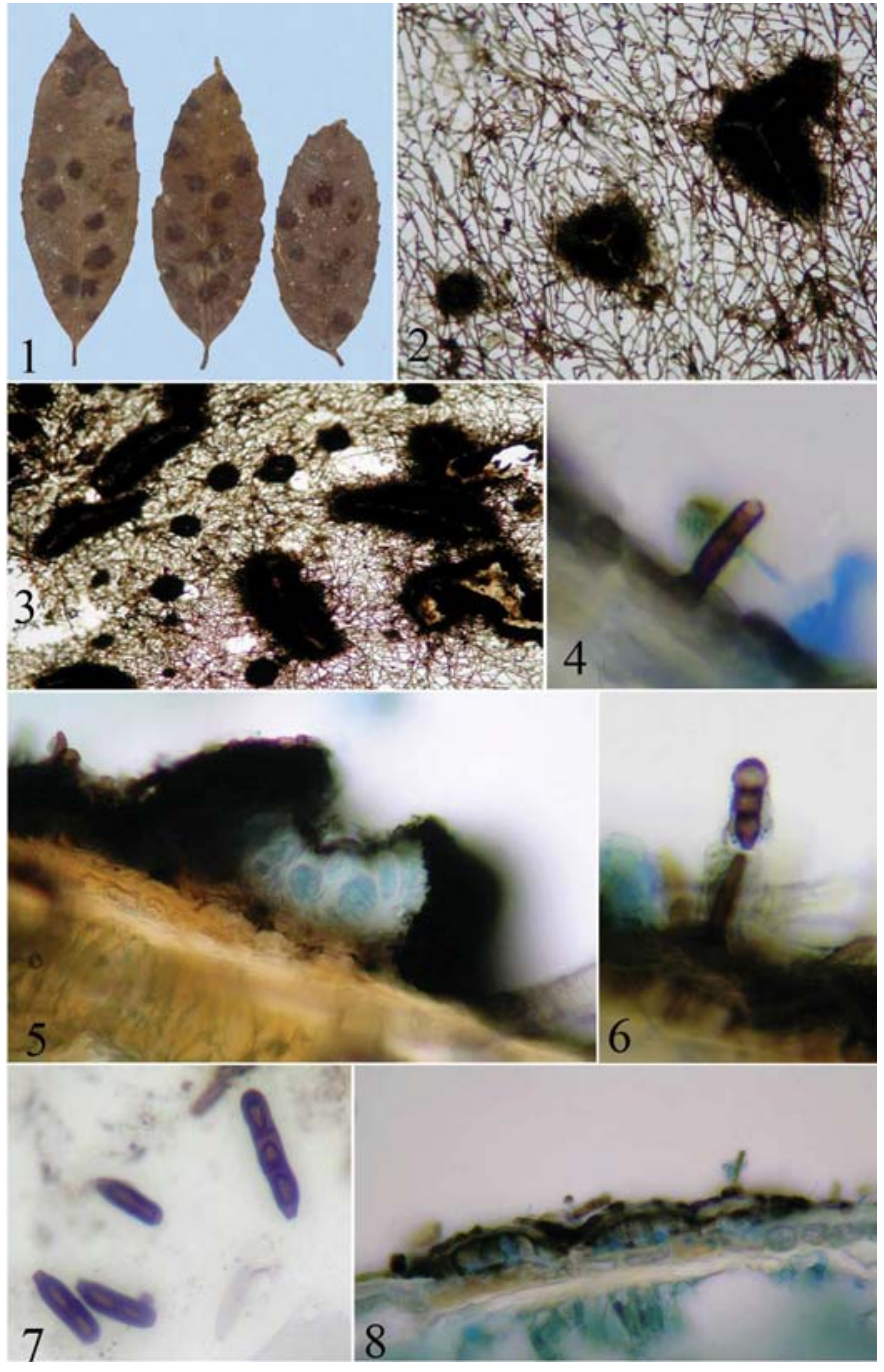

Image 2. Eupelte emicta H. Sydow on Olea dioica

1 - Infected leaves; 2-3 Thyriothecia; 4-6 Conidiophores and releasing conidium; 5 - Thyriothecium with asci; 7 - Conidia; 8 - Fungal mycelium in epidermal cells

wall smooth, 20-48 x 8-10 $\mu \mathrm{m}$. Thyriothecia scattered to grouped, initially orbicular, later elliptic to elongated, simple, straight, curved, often $\mathrm{X}$ or $\mathrm{Y}$ shaped, astomatous, dehisce vertically at the centre, orbicular thyriothecia 100-120 x 90$100 \mu \mathrm{m}$, ellipsoidal thyriothecia 441-700 x 196-245 $\mu \mathrm{m}$; asci born on the basal hymenium, clavate, bitunicate, become spherical at maturity, eight spored, 36-40 x 14-18 $\mu \mathrm{m}$; ascospores conglobate, oblong, brown, uniseptate, constricted at the septa, 17-20 x 9-11 $\mu \mathrm{m}$, wall smooth but becomes verrucose at maturity.

\section{Material examined}

14.xii.2003, On leaves of Olea dioica Roxb. (Oleaceae), Chempatty, Silent Valley National Park, Palghat, Kerala, coll. V.B.Hosagoudar et al. HCIO 46291, TBGT 1937.

Arx \& Müller (1975) have placed Maurodothina G. Arnaud ex Piroz. \& Shoemaker as synonym to Eupelte Syd. Sivanesan (1984) has stated that the genus Eupelte is similar to Maurodothina but differs from it in absence of conidiogenous appressoria. Though this species was reported from India and South Africa (Sivanesan 1975), a detailed study was not made

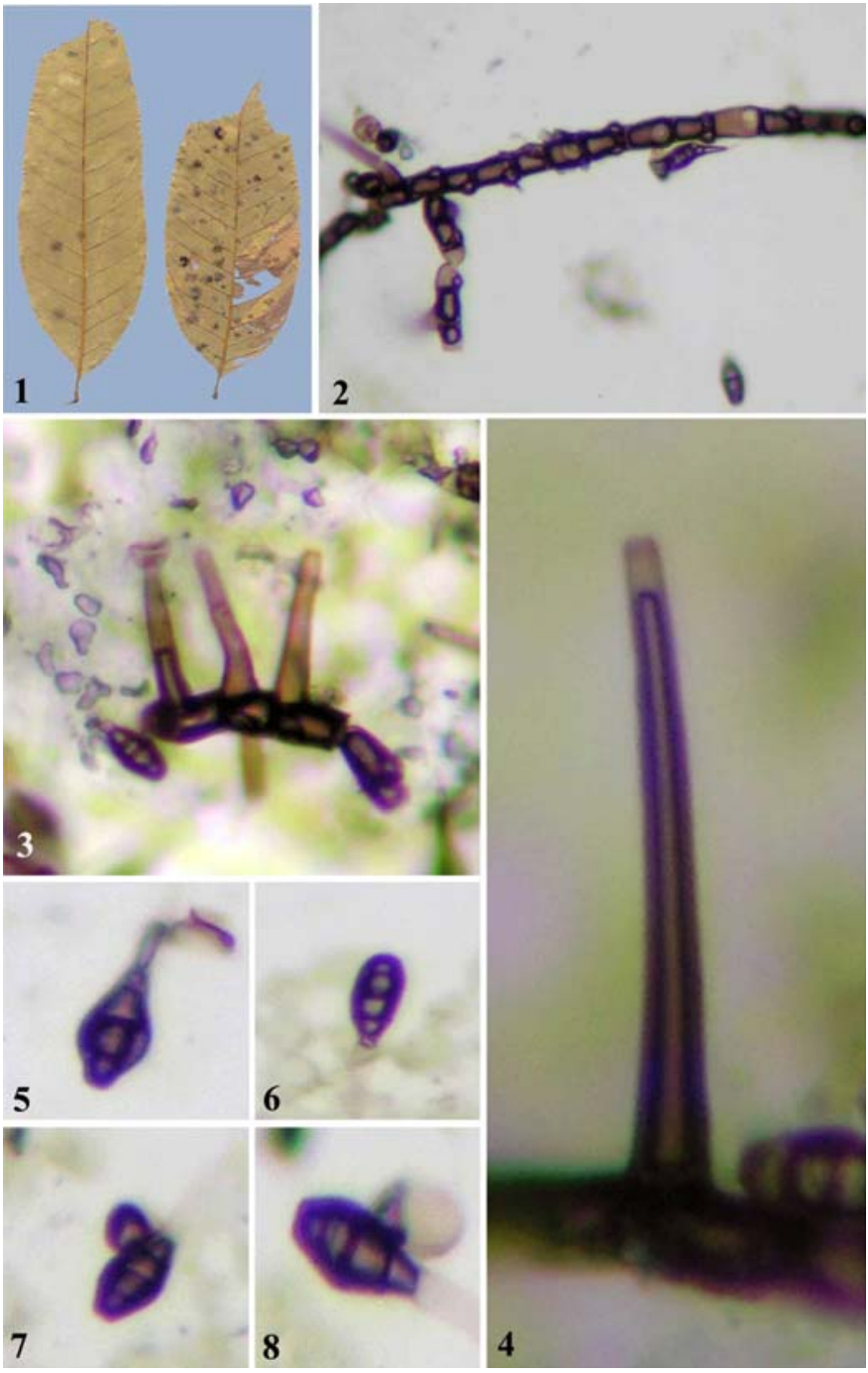

Image 3. Hansfordiellopsis lichenicola (Batista \& Maia) Deighton on Nepheilum sp.

1 - Infected leaves; 2 - Septate mycelium; 3-4 Conidiophores; 5-8 Conidia

from the Indian collections and hence, the note.

\section{Hansfordiellopsis lichenicola (Bat. \& H. Maia) Deighton, Mycol. Pap. 78: 34, 1965: Ellis, Dematiaceous} Hyphomycetes, p. 128, 1971.

(Image 3)

Colonies amphigenous, mostly hypophyllous, subdense to dense, associated with black colony forming fungi having unicellular appressoria. Hyphae ectophytic, brown, septate, slightly constricted at the septa, cells 8-10 x 4-7 $\mu \mathrm{m}$, cells often supplemented with a pair of small, prominent, hemispherical lateral cells without haustorium. Conidiophores macronematous, mononematous, simple, brown, erect, mostly unicellular, 20-30 $\mu \mathrm{m}$ long, slightly taper towards the apex, 3$5 \mu \mathrm{m}$ broad at the base, $1-3 \mu \mathrm{m}$ broad at the apex; conidiogenous cells terminal, determinate, integrated. Conidia solitary, dry, simple, acrogenous, obclavate, rostrate, olivaceous brown, 11$18 \mu \mathrm{m}$ long, $3-4 \mu \mathrm{m}$ broad at the base, $4-6 \mu \mathrm{m}$ broad at the broadest part, $1-2 \mu \mathrm{m}$ broad at the tip of the beak, septa mostly 1-3 in number, horizontal, often oblique, wall smooth. 


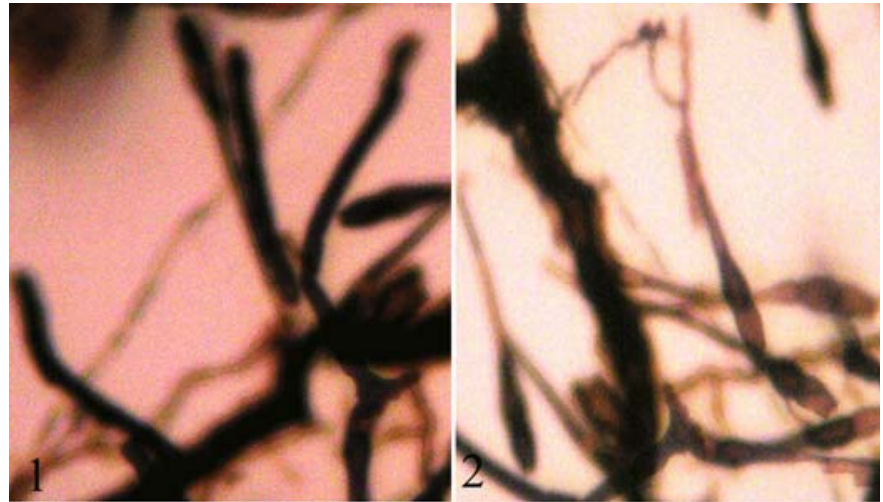

Image 4. Sporidesmium aburiense M.B. Ellis

1 - Conidiophore on the host mycelium; 2 - Conidia

\section{Material examined}

15.xii.2004, On leaves of Nephelium sp. (Sapindaceae), Kakki dam, Pathanamthitta, Kerala, coll. V.B. Hosagoudar et al. HCIO 46319, TBGT 1965.

The genus Hansfordiellopsis Deighton represents five species and all are associated with the foliicolous lichen. This is an anamorph of the genus Koordersiella Hohn. (Kirk et al. 2001). H. lichenicola (Bat. \& Maia) Deighton was known from Brazil, Ghana, Malaysia, Nigeria, Porto Rico, Sarawak, Sierra Leone, Tanzania, Trinidad and Uganda (Ellis 1971) and is known here first time from India and also forms a new generic record to India (Bilgrami et al. 1991; Jamaluddin et al. 2004).

\section{Sporidesmium aburiense M.B. Ellis, Mycol. Pap. 70: 73, 1958; More Diatomaceous Hyphomycetes, p. 82, 1976.}

\section{(Image 4)}

Colonies epiphyllous, brown, hyper parasite. Hyphae superficial, pale yellow, septate, branched, $2-4 \mu \mathrm{m}$ broad. Conidiophores arise from the sides of the hyphae, macronematous, mononematous, simple, straight to flexuous, septate, brown, up to $110 \mu \mathrm{m}$ long and $4-6 \mu \mathrm{m}$ broad. Conidiogenous cells monoblastic, terminal, integrated, percurrent, cylindrical. Conidia brown, solitary, dry, simple, straight to curved, obclavate, rostrate, truncate at the base, 1-3septate, rarely slightly constricted at the septa, paler towards apex, $36-80 \mu \mathrm{m}$ long, $1-2 \mu \mathrm{m}$ broad at the base, $5-7 \mu \mathrm{m}$ broad at the middle, $3-4 \mu \mathrm{m}$ broad at the apex, often a germ tube produced either from the apex or from the base or rarely from both.

\section{Material examined}

12.xi.2003, Overgrowing on the colonies of Cirsocia vateriae on Vateria indica L. (Dipterocarpaceae), Jodupal, Madikeri, Coorg, Karnataka, India, coll. V.B. Hosagoudar HCIO 46380, TBGT 2026.

This species was known on Asterolibertia sp. from Ghana, Sabah and Sierra Leone and is reported here on different fungus for the first time from India (Ellis 1976; Bilgrami et al. 1991, Jamaluddin et al. 2004)

\section{References}

Arx, J.A.V. \& E. Müller (1975). A re-evaluation of the bitunicate ascomycetes with keys to families and genera. Stud. Mycol. 9: 1-159.
Bilgrami, K.S., S. Jamaluddin \& M.A. Rizwi (1991). Fungi of India. List and References. Today and Tomorrow's Printers \& Publishers, New Delhi, pp.1-798.

Ellis, M.B. (1971). Dematiaceous Hyphomycetes. CMI, Kew

Ellis, M.B. (1976). More Dematiaceous Hyphomycetes. CMI, Kew

Hosagoudar, V.B. (2002). Studies on foliicolous fungi -VI.Two new species from Kerala and a new record from India. Zoos' Print Journal 17: 863-866.

Hosagoudar, V.B. (2004). Studies on foliicolous fungi- XI. The genus Balladyna Racib., based on literature. Journal of Economic \& Taxonomic Botany 28: 202-208.

Jamaluddin, M.G. Goswami \& B.M. Ojha (2004). Fungi of India (19892001). Scientific Publishers (India), Jodhpur, 326p.

Kirk, P.M., P.F. Cannon, J.C. David \& J.A. Stalper (2001). Dictionary of the Fungi. CAB International, UK.

Sivanesan, A. (1984). The Bitunicate Ascomycetes. International books \& Periodical supply service, New Delhi (reprint). 